\title{
The application of MTA as apical plug for root canal obturation - in vitro study
}

\author{
Ivan Matović, Dragan V. Ilić, Renata Petrović, Dejan Ostojić \\ University of Belgrade, Faculty of Dental Medicine, Department for Restorative Odontology and Endodontics, Belgrade, Serbia
}

\begin{abstract}
SUMMARY
Introduction Prognosis of endodontically treated tooth is directly correlated to the quality of apical obturation. Modern concept of endodontics in particular way points out the quality of apical filling. The aim of this study was to assess the quality of root canal obturation with MTA apical plug using the method of gas (argon) penetration.

Material and Methods Sixty-six freshly extracted single rooted (single canal) teeth were divided into the two experimental (30 teeth) and one control group (6). All canals were instrumented using hand and rotary files in step-back technique and copious irrigation of $1 \% \mathrm{NaOCl}$. In the first experimental group teeth were obturated using different sealers: Gutta Flow (Roeko), AH Plus (DeTrey), Acroseal (Septodont) and mono gutta-percha cone (10 canals each). In the second experimental group obturation involved $3 \mathrm{~mm}$ of MTA-Angelus apical plug while the remaining canal space was filled with the same three sealers as in the first group. The rate of gas permeability by Leak detector-Edwards LD 416 was measured in all teeth.

Results The best seal was found in teeth obturated with Gutta Flow and MTA plug with average diffusion rate of 264.4 sec while the worst quality of obturation was found with Acroseal (178.5 sec-the highest gas permeability). All samples with MTA plug exhibited significantly lower leakage than the samples filled without MTA apical plug.

Conclusion Root canals filled with MTA apical plug exhibited statistically significant lower gas permeability in comparison to the ones filled with sealer and guttapercha cones only.

Keywords: MTA; sealer; apical obturation; Gutta Flow; calcium silicate; gas permeability
\end{abstract}

\section{INTRODUCTION}

Adequately done endodontic treatment supports and stimulates reparative processes in apical periodontal tissues. Up to date doctrine of endodontic treatment is based on biomechanical canal instrumentation and irrigation [1]. The idea about optimal apical hermetic sealing with biologic properties forced many investigators to find ideal obturation material that could also prevent overfilling $[2,3]$. This material needed to be biocompatible, adhesive and physico-chemically stable to perform obturation $[4,5]$. Mineral trioxide aggregate (MTA) material fulfills many of required characteristics [5]. Torabinejad and Asgary were the first ones to use MTA in vitro and then in vivo studies in restorative and endodontic procedures in the nineties of the past century [5]. It was invented to improve and satisfy appropriate hardness, low solubility and short setting time as obturation material. The first dark-gray variant of MTA was mostly based on hydroxyapatite particles [4], similar to the original Portland cement (PC) formulation. It has been examined through the series of physicochemical and biological tests for use in dentistry as cheaper bioactive dentine replacement material besides expensive MTA [5-8]. Up to nowadays, many variants of CS cements showed impressive results as endodontic sealers, pulp-capping agents, apical retrograde fillings $[9,10]$ apical obturation sealers $[11,12]$, perforation healing liners [13], as well as propelling agent during apexogenesis/apexification [12, 13]. One of CS preparations, an improved MTA cement, iRoot cement (iR) as root canal sealer is confirmed to kill E. faecalis in bacterial medium [14]. It is considered bioactive material but with high toxicity and certain antibacterial properties [15, 16]. Methods for evaluation of apical hermeticity are numerous but diffusion of dye is the one most frequently used, whether by vacuum system or without. Similar methods were used at the end of past century, but with more precision, displaying apical permeability through the function of time $[17,18]$.

The aim of this study was to assess the canal filling hermeticity of MTA apical plug using the method of gas diffusion.

\section{MATERIAL AND METHODS}

The study involved sixty-six extracted single-rooted teeth grouped into the two experimental groups of 30 teeth each and one control group of six teeth. The used endodontic sealers were: Gutta Flow (Colthane /Whaledent, Germany), AH Plus (DeTrey, Germany) and Acroseal (Septodont, France). Standardized gutta-percha cones of $2 \%$ taper were used for obturation (Pearl Endopia, Pearl Dent Co.). In the first group (A) canals were obturated with single gutta-percha cone and sealer. The second group (B) had canals obturated with apical MTA plug and rest of the canal with gutta-percha and sealer. The roots of teeth had similar diameter and volume of apical portion without any defect along the root. The coronal part of the teeth was removed from the root at the cement-enamel junction using high-speed hand-piece and 


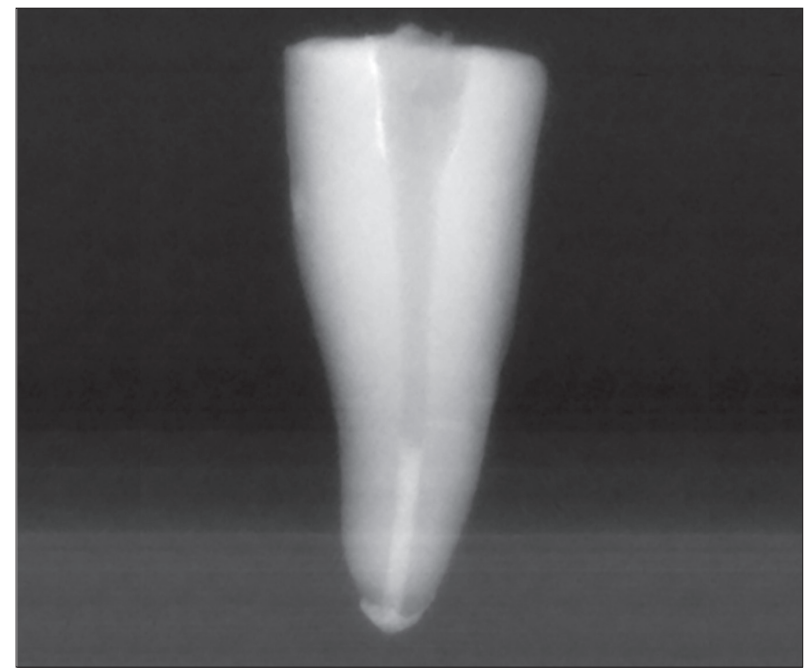

Figure 1. $X$ ray of the root canal after the placement of apical filling (plug) using MTA cement

Slika 1. Kontrolna radiografija korena posle punjenja apeksnog dela kanala MTA cementom

fissure diamond bur enabling direct access to the canal. After the initial patency (Kerr files \#10 and \#15), preoperative radiograms were performed. Pulp tissue was removed using barbed broach. Working length was determined by insertion of hand file into the canal until it goes out through the apex and then subtraction for $1 \mathrm{~mm}$ and taking xray. Canals were prepared to the $\mathrm{WL}$ (\#15 do \#40) and then by step-back technique up to the coronal third of canal using copious irrigation $(1 \% \mathrm{NaOCl})$ and lubricant (Canal + , Septodont, France). Instrumentation was completed with hand Ni-Ti reamers and files (Sybron, Germany).

\section{Experimental groups}

Upon canal preparation (apical matrix of \#40 size) root canals were obturated with three sealers and single gutta-percha cone (groups A1, B1 and C1) or with previously inserted MTA plug by pluggers for vertical condensation (Maillefer, Swiss) and then sealer and gutta-percha cone in the groups A2, B2 and C2. Obturation was performed using Lentulo spiral and guttapercha cones in combination with endodontic sealers: Gutta Flow, Acroseal and AH Plus (DeTray, Germany). Gutta Flow was inserted using dispensing gun (Coltene/Whaledent, Swiss).

Apical plug was $3 \mathrm{~mm}$ long where periapical radiographs from two directions confirmed the quality of apical MTA filling (Figure 1). Access cavities were temporary filled with Cavit (Premier, Dental Products, Germany).

Control group involved six canals that were obturated only with gutta-percha cones to show that argon (Ar) is capable of going only through the apical foramen and root canal filling material. The teeth of experimental and control group were kept for 7 days at $37^{\circ} \mathrm{C}$ in the area of absolute humidity to allow definite hardening of sealers.

\section{Gas diffusion marking}

Quantification of visual information was done using VegaCam device (Edwards LD, 416, UK) and detector device by added software program (Argon Leak Detector, Edwards, UK). The quality of root canal obturation was assessed using the technique of gas permeability system [18]. Ar concentration was measured using argon-leak detector (Edwards LD 416, UK) [18]. Obturated teeth were fixed in prospecting detectors for stability. Argon gas was introduced by a special micro-cannula placed in the coronal part of canal when the measurement chamber was vacuumed. The time (sec) needed for gas penetration through the apex was measured using the timer [19]. The quality of obturation was expressed as the time interval needed for Ar to penetrate through the apex whereby longer time meant better obturation.

Statistical analysis was performed using ANOVA test for differences between the means of experimental groups using confidentiality level of $p=0.01$. Newman-Keuls test was used to compare differences between the groups.

\section{RESULTS}

In the group of teeth that were obturated with apical MTA plug, the lowest gas permeability was shown by combined obturation with Gutta Flow and MTA apical plug $(269.4 \mathrm{sec})$, then AH Plus and MTA plug $(258.5 \mathrm{sec})$ while the highest gas permeability was with Acroseal and MTA plug $(255.2 \mathrm{sec})$. The differences among them were statistically insignificant $(\mathrm{p}>0.01)$ (Table 1, Graph 1).

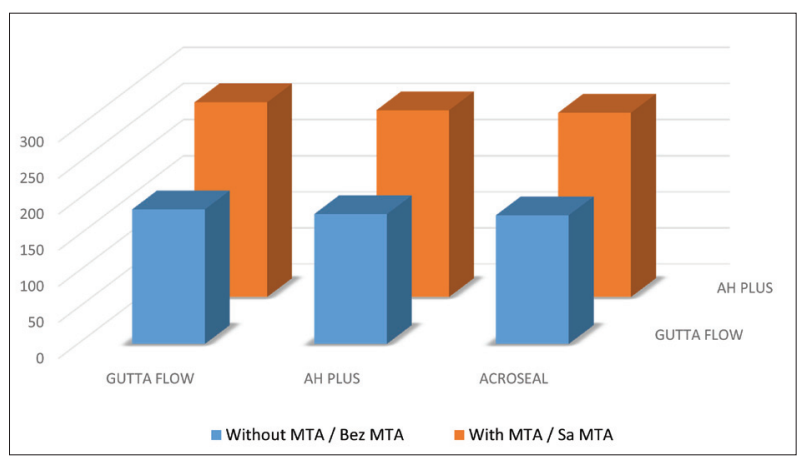

Graph 1. Comparative values of the time (sec) required for argon diffusion from coronal part of restoration to the apex (groups of teeth with sealer and gutta-percha without MTA plug and groups with sealer and gutta-percha and MTA plug)

Grafikon 1. Uporedne vrednosti vremena (sek.) potrebne za difuziju argona od kruničnog dela ispuna do apeksa kod grupe $\mathrm{A} 1, \mathrm{~B} 1 \mathrm{i}$ C1 prema grupama $\mathrm{A} 2, \mathrm{~B} 2 \mathrm{i}$ C2

Table 1. Average time needed for argon diffusion (sec) throughout the root canal filling

Tabela 1. Srednja vrednost brzine prodora argona (sek.) kroz kanalsko punjenje

\begin{tabular}{|c|c|c|c|}
\hline $\begin{array}{l}\text { Material } \\
\text { Materijal }\end{array}$ & $\begin{array}{l}\text { Sample } \\
\text { Uzorak }\end{array}$ & $\begin{array}{l}\text { Variance } \\
\text { Varijansa }\end{array}$ & $\begin{array}{c}\text { Mean value of } \mathrm{Ar} \\
\text { diffusion rate (sec) } \\
\text { Srednja vrednost brzine } \\
\text { prodora argona (sek.) }\end{array}$ \\
\hline$A_{1}-$ Gutta flow & 10 & 21.35 & 186.7 \\
\hline $\mathrm{A}_{2}-$ Gutta flow + MTA & 10 & 27.02 & 269.4 \\
\hline \multicolumn{4}{|l|}{$F=0.73, p<0.01$} \\
\hline $\mathrm{B}_{1}-\mathrm{AH}$ Plus & 10 & 21.85 & 179.9 \\
\hline $\mathrm{B}_{2}-\mathrm{AH}$ Plus + MTA & 10 & 41.23 & 258.5 \\
\hline \multicolumn{4}{|l|}{$F=1.50, p<0.01$} \\
\hline$C_{1}-$ Acroseal & 10 & 31.24 & 178.5 \\
\hline $\mathrm{C}_{2}-$ Acroseal + MTA & 10 & 33.54 & 255.2 \\
\hline \multicolumn{4}{|l|}{$F=1.87, p<0.01$} \\
\hline
\end{tabular}


In the group of teeth that were obturated with no apical MTA plug, the lowest gas permeability was recorded in Gutta Flow samples (186.7 sec) then AH Plus (179.9sek) and the highest permeability in the Acroseal paste samples $(178.5 \mathrm{sec})$. The differences among them were statistically insignificant ( $p>0.01)$. The MTA samples showed statistically significant lower argon leakage in comparison to the ones obturated only with sealer and gutta-percha cones without MTA plug $(\mathrm{p}<0.05)$.

\section{DISCUSSION}

MTA has characteristics of bioactive material and it is known for its use as an apical plug with good physico-chemical properties exhibiting good adherence to dentin, compressive strength and push-out forces $[4,7,8,20,21]$. Moreover, its positive biological properties such as biostimulative, osteoconductive and antimicrobial effects have been confirmed either on animal model or in clinical conditions (pulp capping, pulpotomy, root perforations) $[4,6,7,8,19,20]$.

Several methods have been used for the evaluation of apical hermeticity such as bacterial penetration [21], electric currency [22], dye diffusion [2] and radioactive agents [23]. Gas permeability method has good value in assessing the quality of canal obturation. Due to the use of different gases in this method (Ar, $\mathrm{O}_{2}, \mathrm{~N}_{2}, \mathrm{CO}_{2}$, noble gases, organic gases), comparison of the results with different gas nature or different experimental models may not be possible $[18,19]$. Argon as the noble element was chosen for our study due to its inactivity to endodontic sealers $[18,19]$. However, this method only allows assessing overall permeability without showing the path of its diffusion. In addition, combined argon diffusion with optical analysis (XRD and spectrophotometry) could possibly explain physical phenomenon of leakage events $[18,24]$.

MTA was chosen as most commonly used cement in several investigations $[4-9,15,25,26]$ and due to its biocompatibility, high alkalinity and low solubility [2,27]. Our satisfying results obtained by MTA-plug could be explained by its low solubility due to water absorption and minimal expansion that was confirmed in several studies $[8,9,12,23,27,28]$.

The use of iR as sealer or filler and for reparation of canal-wall perforation presented satisfactory results [27] due to missing alumina particles and resemblance to white MTA. iR is considered appropriate for root canal filling material due to its viscosity [28] and could be used as sealer-filler with or without gutta-percha cones [29].

The advantage of combination of MTA apical plug and sealer over sealer only samples in the current study may be explained by its expansion in the first several hours during setting and water absorption when MTA exposed weight increase around $12 \%$ upon submerging for $24 \mathrm{~h} \mathrm{[30].}$

Low solubility and good adherence to the canal walls of Gutta Flow and AH Plus paste has been shown in several studies $[17,18,31,32]$. Our results are consistent with the results of the study of Bracket et al. [33] and Bouillaguet et al. after 12 months follow-up [34]. Bouillaguet et al. explained that in single-cone obturation technique the volume of sealer is higher than the volume of gutta-percha, and this ratio promotes void formation and reduces the quality of seal due to the contraction phenomenon. Use of single-cone technique also allowed comparison of the performance of all materials under relatively standardized conditions. Leakage of AH-Plus may have resulted from inadequate bonding between sealer and gutta-percha cone allowing fluid to flow at the interface. This finding is in agreement with the results from Sagsen et al. [29]. Bouillaguet et al. also considered that gun pressure for sealer injection created better adhesion of Guta Flow than AH Plus to the canal walls and consequently lower micro-leakage. Martin et al. based of bacterial canal penetration confirmed better sealability in $\mathrm{AH}$ Plus cases than when Gutta Flow paste was used as obturation material [35].

Acroseal as calcium-hydroxide based sealer showed inadequate (poor) hermeticity and that finding is also in accordance with several studies $[34,36]$. As per Mc Michen et al. AH Plus was more stable than Acroseal that was also confirmed in the current study [37].

The explanation for better apical hermeticity in canals obturated by MTA apical plug than in samples without MTA plug was demonstrated in the study of Guven et al. [38]. They explained this finding by the nanosphere structure of MTA particles that allows the material to penetrate into dentinal tubules and interact with moisture inside the tubules for final setting. This creates mechanical bond with dentin upon setting and renders the material with exceptional dimensional stability. In addition, many MTA brands provided either water or hydrosoluble gel to improve its washout resistance.

Nowadays, more improved MTA-based sealers (BioRoot ${ }^{\mathrm{TM}}$ - RCS, MTA caps ${ }^{\mathrm{R}}$, iR ${ }^{\mathrm{R}}$, iR- BP PlusMTA-Fillapex ${ }^{\mathrm{R}}$ [27], Biodentine $^{\mathrm{TM}}$ [27], Bioaggregate ${ }^{\mathrm{R}}$ [38], ProRoot $\mathrm{MTA}^{\mathrm{R}}$ [39]) are more insoluble than original MTA formula in vivo and in vitro. For their safe clinical use further research is required.

\section{CONCLUSIONS}

Root canal obturation with different sealers, gutta-percha and MTA apical plug demonstrated significantly lower gas penetration compared to standard technique that included guttapercha and sealer without MTA plug.

\section{REFERENCES}

1. Oliver CM, Abbott PV. Correlation between clinical success and apical dye penetration. Int Endod J. 2001; 34(8):637-44. [DOI: 10.1046/j.1365-2591.2001.00442] [PMID: 11762501]

2. Murphy WM. The testing of endodontic materials in vitro. Int Endod ). 1988; 21(2):170-7.

[DOI: 10.1111/j.1365-2591.1988.tb00971.x] [PMID: 3268553]

3. Fogel BB. A comparative study of five materials for use in filling root canal spaces. Oral Surg Oral Med Oral Pathol. 1977; 43(2):284-99. [PMID:64952]

4. Asgary S, Shahabi S, Jafarzadeh T, Amini S, Kheirieh S. The properties of a new endodontic material. J Endod. 2008; 34(8):990-3. [DOI: 10.1016/j.joen.2008.05.006] [PMID: 18634932]

5. Torabinejad M, Watson TF, Pitt Ford TR. Sealing ability of a mineral trioxide aggregate when used as a root end filling material. J Endod. 1993; 19(12):591-5. [DOI: 10.1016/S0099-2399(06)80271-2] [PMID: 8151252]

6. De Deus G, Ximenes R, Gurgel-Filho ED, Plotkowski MC, CoutinhoFilho T. Cytotoxicity of MTA and Portland cement on human ECV 304 endothelial cells. Int Endod J. 2005; 38(9):604-9. [DOI: 10.1111/j.1365-2591.2005.00987] [PMID: 16104973] 
7. Torabinejad M, Parirokh M. Mineral trioxide aggregate: a comprehensive literature review-part II: leakage and biocompatibility investigations. J Endod. 2010; 36(2):190-202.

[DOI: 10.1016/j.joen.2009.09.010] [PMID: 20113774]

8. Parirokh M, Torabinejad M. Mineral trioxide aggregate: a comprehensive literature review-Part I: chemical, physical, and antibacterial properties. J Endod. 2010; 36(1):16-27.

[DOI: 10.1016/j.joen.2009.09.006] [PMID: 20003930]

9. Watson TF, Atmeh AR, Sajini S, Cook R], Festy F. Present and future of glass-ionomers and calcium-silicate cements as bioactive materials in dentistry: biophotonics-based interfacial analyses in health and disease. Dent Mater. 2014; 30(1):50-61.

[DOI: 10.1016/j.dental.2013.08.202] [PMID: 24113131]

10. Biočanin V, Antonijević Đ, Poštić S, Ilić D, Vuković Z, Milić M, et al. Marginal Gaps between 2 Calcium Silicate and Glass lonomer Cements and Apical Root Dentin. J Endod. 2018; 44(5):816-21. [DOI: 10.1016/j.joen.2017.09.022] [PMID: 29336880]

11. Kadić S, Baraba A, Miletić I, lonescu A, Brambilla E, Ivanišević Malčić A, et al. Push-out bond strength of three different calcium silicate-based root-end filling materials after ultrasonic retrograde cavity preparation. Clin Oral Investig. 2018; 22(3):1559-65. [DOI: 10.1007/s00784-017-2244-6] [PMID: 29063381]

12. Bosso-Martelo R, Guerreiro-Tanomaru JM, Viapiana R, Berbert FL, Basso Bernardi MI, Tanomaru-Filho M. Calcium silicate based cements associated with micro and nanoparticle radiopacifiers: physicochemical properties and bioactivity. Int Sch Res Notices. 2015; 2015:874283. [DOI: 10.1155/2015/874283] [PMID: 27347552]

13. Lemos MSS, Gabardo MC, Castiglia Gonzaga C, Dias Morais N, Baratto-Filho F, Correr Nolasco GM, et al. Bond strength of selfadhesive resin cement to different root perforation materials. J Endod. 2016; 42(12):1819-21. [DOI: 10.1016/j.joen.2016.08.019] [PMID: 27769677]

14. Dawood AE, Parashos P, Wong RHK, Reynolds EC, Manton DJ. Calcium silicate-based cements: composition, properties, and clinical applications. J Investig Clin Dent. 2017; 8:2.

[DOI: 10.1111/jicd.12195] [PMID: 26434562]

15. Zhaofei L, Cao L, Fan M, Xu Q. Direct pulp capping with calcium hydroxide or Mineral Trioxide Aggregate: A Meta-analysis. I Endod. 2015; 41(9):1412-7. [DOI: 10.1016/j.joen. 2015.04.012] [PMID: 25990198]

16. De-Deus G, Canabarro A, Alves GG, Marins JR, Linhares AB, Granjeiro JM. Cytocompatibility of the ready-to-use bioceramic putty repair cement iRoot BP Plus with primary human osteoblasts. Int Endod J. 2012; 45(6):508-13.

[DOI: 10.1111/j.1365-2591.2011.02003] [PMID: 22364572]

17. Parirokh $M$, Torabinejad $M$, Dummer PMH. Mineral trioxide aggregate and other bioactive endodontic cements: an updated overview-part I: vital pulp therapy. Int Endod J. 2018; 51(2):177-205. [DOI: 10.1111/iej.12841] [PMID: 28836288]

18. Djordjević M, Lapcević A, Jovanić P, Jevremović DP, Puskar T, Jovanić PB. Hydroxyapatite activation analysis using $x$ ray diffraction FT-IR spectroscopy and SEM. Healthmed. 2012; 6(7):2537-42.

19. Matović I, Teodorović N, Marjanović M. Evaluation of root canal obturation using gas permeability method. Stom Glas S. 2013; 60(2):63-8. [DOI: 10.2298/SCS1302063M]

20. Torabinejad $M$, Chivian N. Clinical applications of mineral trioxide aggregate. J Endod. 1999; 25(3):197-205.

[DOI: 10.1016/S0099-2399(99)80142-3] [PMID: 10321187]

21. Schwartz RS, Mauger M, Clement DJ, Walker WA. Mineral trioxide aggregate: a new material for endodontics. I Am Dent Assoc. 1999; 130(7):967-75. [PMID: 10422400]

22. Sisodia R, Ravi KS, Shashikiran ND, Singla S, Kulkarni V. Bacterial penetration along different root canal fillings in the presence or absence of smear layer in primary teeth. J Clin Pediatr Dent. 2014; 38(3):229-34. [PMID: 25095317]

23. Aydemir H, Ceylan G, Tasdemir T, Kalyoncuoglu E, Isildak I. Effect of immediate and delayed post space preparation on the apical seal of root canals obturated with different sealers and techniques. J Appl Oral Sci. 2009; 17(6):605-10. [PMID: 20027435]

24. Puppala R, Hegde A, Munshi AK. Laser and light cured composite resin restorations: in-vitro comparison of isotope and dye penetrations. J Clin Pediatr Dent. 1996; 20(3):213-8. [PMID: 8634208]

25. Singh S, Podar R, Dadu S, Kulkarni G, Purba R. Solubility of a new calcium silicate-based root-end filling material. J Conserv Dent. 2015; 18(2):149-53. [DOI: 10.4103/0972-0707.153053] [PMID: 25829696]

26. Guneser MB, Akbulut AU, Eldeniz MB. Effect of various endodontic irrigants on push-out bond strength of Biodentine and conventional root perforation repair materials. J Endod. 2013; 39(3):380-4. [DOI: 10.1016/j.joen.2012.11.033] [PMID: 23402511]

27. Parirokh M, Torabinejad M. 10 Calcium Silicate-Based Cements. Pocket Dentistry. Available at: https://pocketdentistry.com/10calcium-silicate-based-cements/

28. Nagas E, Uyanik MO, Eymirli A, Cehreli ZC, Vallittu PK, Lassila LV, et al. Dentin moisture conditions affect the adhesion of root canal sealers. J Endod. 2012; 38(2):240-4. [DOI: 10.1016/j.joen.2011.09.027] [PMID: 22244645]

29. Sagsen B, Ustün Y, Demirbuga S, Pala K. Push-out bond strength of two new calcium silicate-based endodontic sealers to root canal dentine. Int Endod J. 2011; 44(12):1088-91.

[DOI: 10.1111/j.1365-2591.2011.01925] [PMID: 21895700]

30. Camilleri J. The physical properties of accelerated Portland cement for endodontic use. Int Endod J. 2008; 41(2):151-7.

[DOI: 10.1111/j.1365-2591.2007.01330] [PMID: 17931386]

31. Guimarães BM, Vivan RR, Piazza B, Alcalde MP, Bramante CM, Duarte MAH. Chemical-physical Properties and apatite-forming ability of Mineral Trioxide Aggregate flow. J Endod. 2017; 43(10):1692-96. [DOI: 10.1016/j.joen.2017.05.005] [PMID: 28735787]

32. Razmi H, Parvizi S, Khorshidian A. Comparison of AH26 physicochemical properties with two AH26/antibiotic combinations. Iran Endod J. 2010; 5(1):6-10. [PMID: 23130022]

33. Brackett MG, Martin R, Sword J, Oxford C, Rueggeberg FA, Tay $F R$, et al. Comparison of seal after obturation techniques using a polydimethylsiloxane-based root canal sealer. J Endod. 2006; 32(12):1188-90. [DOI: 10.1016/j.joen.2006.07.009]

[PMID: 17174680]

34. Bouillaguet S, Shaw L, Barthelemy J, Krejci I, Wataha JC. Long-term sealing ability of Pulp Canal Sealer, AH-Plus, GuttaFlow and Epiphany. Int Endod J. 2008; 41(3):219-26.

[DOI: 10.1111/j.1365-2591.2007.01343] [PMID: 18005042]

35. Martin RL, Monticelli F, Brackett W, Loushine RJ, Rockman RA, Ferrari $M$, et al. Sealing properties of mineral trioxide aggregate orthograde apical plugs and root fillings in an in vitro apexification model. J Endod. 2007; 33(3):272-5. [DOI: 10.1016/j.joen.2006.11.002] [PMID: 17320712]

36. Eldeniz AU, Ørstavik D. A laboratory assessment of coronal bacterial leakage in root canals filled with new and conventional sealers. Int Endod J. 2009; 42(4):303-12.

[DOI: 10.1111/j.1365-2591.2008.01509] [PMID: 19220520]

37. McMichen FR, Pearson G, Rahbaran S, Gulabivala K. A comparative study of selected physical properties of five root-canal sealers. Int Endod J. 2003; 36(9):629-35. [PMID: 12950578]

38. Hashem AA, Wanees Amin SA. The effect of acidity on dislodgement resistance of mineral trioxide aggregate and bioaggregate in furcation perforations: an in vitro comparative study. I Endod. 2012; 38(2):245-9. [DOI: 10.1016/j.joen.2011.09.013] [PMID: 22244646]

39. Guven Y, Tuna EB, Dincol ME, Ozel E, Yilmaz B, Aktoren O. Longterm fracture resistance of simulated immature teeth filled with various calcium silicate-based materials. Biomed Res Int. 2016; 2016:2863817. [DOI: 10.1155/2016/2863817] [PMID: 27382564]

Received: 01.03.2018 • Accepted: Prihvaćen 21.05.2018 


\title{
Primena MTA kao apeksnog čepa u opturaciji kanala korena zuba - in vitro studija
}

\author{
Ivan Matović, Dragan V. Ilić, Renata Petrović, Dejan Ostojić \\ Univerzitet u Beogradu, Stomatološki fakultet, Klinika za restaurativnu odontologiju i endodonciju, Beograd, Srbija
}

\begin{abstract}
KRATAK SADRŽAJ
Uvod Prognoza uspeha endodontski treatiranih zuba je u direktnoj korelaciji sa kvalitetom opturisanog endodontskog prostora. Savremena koncepcija endodontskog tretmana poseban akcenat stavlja na kvalitet preparacije i opturacije apeksnog dela kanala. Cilj ovog rada je bio da se metodom merenja gasne propustljivosti (argona) proveri kvalitet opturacije kanala korena zuba nakon primene mineral-trioksid agregata (MTA) kao apeksnog čepa.

Materijal i metod U istraživanje je uključeno 66 jednokorenskih-jednokanalskih zuba razvrstanih u dve grupe (po 30 zuba), dok je šest zuba korišćeno kao kontrola. Preparacija svih kanala je urađena ručnim instrumentima i primenom step-back tehnike uz obilnu irigaciju $1 \% \mathrm{NaOCl}$. U prvoj grupi zuba je opturacija realizovana silerima uz pomoć gutaperka konusa Gutta Flow-Roeko (10), AH Plus-DeTrey (10) i Acroseal-Septodont (10). Drugu grupu su činili zubi kod kojih je u apeksnom delu kanala aplikovan MTA, a potom su kanali ispunjeni primenom tri silera kao u prvoj grupi. Svi zubi iz obe grupe su podvrgnuti metodi merenja brzine gasne propustljivosti pomoću aparata Argon Leak Detector, Edwards LD 416.

Rezultati Najbolju hermetičnost su pokazali uzorci kanala ispunjeni primenom Gutta Flow+MTA sa prosečnom brzinom (264,4 sek.), a najslabiji kvalitet opturacije sa Acroseal silerom (najveća gasna propustljivost 178,5 sek.). Svi uzorci druge grupe sa MTA čepom su pokazali statistički značajno manju propustljivost nego oni u prvoj grupi sa silerom i gutaperkom bez MTA čepa.

Zaključak Opturacija kanala sa postavljenim MTA apeksnim čepom pokazala je značajno manju propustljivost gasa u poređenju sa uzorcima ispunjenim endodontskim silerom i gutaperka konusima.

Ključne reči: MTA; siler; apeksna opturacija; Gutta Flow; kalcijum-silikat; propustljivost gasa
\end{abstract}

\section{UVOD}

Uspešan endodontski tretman značajno utiče na tok reparatornih procesa u apeksnom periodoncijumu. Savremeni aspekt endodontskog lečenja bazira se na adekvatnoj biomehaničkoj kanalskoj instrumentaciji odnosno apeksnoj medikaciji kao njen značajni faktor [1]. Ideju o optimalnoj apeksnoj hermetičnosti punjenja sa biološkim svojstvima forsiraju mnogi istraživači jer bi materijal u vidu čepa trebalo da, između ostalog, spreči prebačaj materijala u periapeksne strukture [2,3]. U tom smislu se koriste materijali koji poseduju biokompatibilnost, dobru adhezivnost, kao i ostale stabilne fizikohemijske parametre važne za opturaciju kanala korena $[4,5]$. Torabinejad i Asgary su u in vitro [4] a zatim in vivo [5] radovima prvi put primenili novi materijal, mineral-trioksid agregat (MTA), vrstu kalcijumsilikatnog cementa (KS) $[4,5]$ devedesetih godina prošlog veka. Uveden je sa ciljem da poboljša i zadovolji čvrstoću, nizak nivo rastvorljivosti i kratko vreme očvršćavanja kao materijal za opturaciju. Prva tamnosiva varijanta MTA je uglavnom bila sa česticama hidroksiapatita [4], slična Portland cementu (PC). Ovaj novi obećavajući materijal počinje da biva predmet istraživanja $\mathrm{u}$ vezi sa fizikohemijskim i biološkim osobinama za primenu u stomatologiji kao jeftiniji materijal u odnosu na MTA [5-8]. Sve do danas, varijante KS cemenata su pokazale ohrabrujuće rezultate kao endodontski sileri, sredstva za prekrivanje pulpe, kao apeksni retrogradni ispuni $[9,10]$, kao sredstva za slučajeve perforacija zida kanala, kao lajneri [11] ili ubrzavajući faktor apeksogeneze/apeksifikacije $[12,13]$. Potvrđeno je čak da je jedna od MTA preskripcija (iRoot cement), kao endodontski siler, sposoban da uništi E. faecalis u bakterijskom medijumu [14]. On se smatra bioaktivnim materijalom $[15,16]$ ali sa visokom citotoksičnošću i izvesnim antibakterijskim osobinama. Metode za procenu hermetičnosti su brojne, pri čemu je metoda difuzije boje jedna od najčešćih, bilo da se koristi u vakuumu ili u normalnim uslovima. Sličan metod, koji je takođe vrlo precizan, korišćen je krajem prošlog veka i bazira se na apeksnoj gasnoj propustliivosti u funkciji vremena $[17,18]$.

Iz tog razloga je cilj ovog rada bio da se metodom gasne propustljivosti proveri kvalitet hermetičnosti kanalskog punjenja nakon primene MTA kao apeksnog čepa.

\section{MATERIJAL I METOD}

U istraživanju je korišćeno 66 ekstrahovanih jednokorenih zuba podeljenih u dve eksperimentalne grupe (po 30), dok je šest zuba korišćeno za kontrolu. Kao endodontski sileri su korišćeni: Gutta Flow-Colthane/Whaledent, Germany; AH Plus, De Trey, Germany; Acroseal, Septodont, France za opturaciju. Pri opturaciji su standardizovani gutaperka kočići koniciteta 2\% (Pearl Endopia, Pearl Dent Co., Vietnam). U grupi A su bili kanali ispunjeni silerom i gutaperka kočićima, a u grupi B oni ispunjeni prvo MTA apeksnim čepom, a preostali deo silerom i gutaperka kočićima. Korenovi zuba su bili približno sličnog dijametra i volumena apeksne trećine korena bez ikakvog defekta duž korena zuba. Krunični deo zuba je odsečen od korena na gleđno-cementnoj granici korišćenjem visokoturažne bušilice i fisurnog dijamantskog svrdla omogućavajući direktan pristup kanalu. Posle inicijalne prohodnosti (Kerr turpije \#10 i \#15) urađen je preoperativni radiogram. Pulpno tkivo je uklonjeno pulpekstirpatorom. Radna dužina za sve zube je određena umetanjem proširivača u kanal i radiografisanjem sa endodontskim proširivačem na $1 \mathrm{~mm}$ kraće od anatomskog foramena. Apeksna matrica je formirana na tom nivou serijskim proširivanjem \#15 do \#40, a zatim step back tehnikom do krunične trećine kanala uz obilnu irigaciju. Za kanalsku insrumentaciju korišćeni su ručni NiTi proširivači (Sybron, Germany) uz irigaciju $1 \% \mathrm{NaOCl}$ i lubrikant (Canal +, Septodont, France). 


\section{Eksperimentalne grupe}

Posle apeksne preparacije veličine \#40 kanali su opturisani primenom tri silera i gutaperka konusa bilo kao standardna kombinacija (grupe A1, B1 i C1) ili sa prethodno umetnutim MTA čepom kompakterima za vertikalnu kompakciju (Maillefer, Swiss) u grupama (A2, B2 i C2). Opturacija je sprovedena korišćenjem Lentulo spirale i gutaperka konusa kombinovanog sa endodontskim silerom Gutta Flow (Roeco, Germany), Acroseal (Septodont, France) i AH Plus (DeTray, Germany). Gutta Flow siler je aplikovan pištoljem (Coltene/Whaledent dispensing gun, Swiss). Apeksni MTA čep je bio debljine $3 \mathrm{~mm}$, pri čemu je retroalveolarnim snimkom iz dva pravca proveren kvalitet ispuna (Slika 1). Pristupni kaviteti su privremeno zatvarani ispunom Cavit (Premier, Dental Products, Germany).

Kontrolnu grupu je činilo šest zuba, kod kojih su kanali opturisani samo gutaperka konusima sa ciljem da pokažu da je argon (Ar) sposoban da prođe samo kroz masu kanalskog ispuna i apeks. Zubi eksperimentalnih i kontrolnih grupa su stajali sedam dana na $37^{\circ} \mathrm{C}$ u sredini apsolutne vlažnosti da omoguće definitivno očvršćavanje silera.

\section{Markiranje difuzije gasa}

Sistem za kvantifikaciju vizuelnih informacija sastojao se od kamere (VegaCam, Edwards LD 416, UK) i detektorskog uređaja sa odgovarajućim softverskim programom (Argon Leak Detector, Edwards, UK). Kvalitet kanalne opturacije je kontrolisan tehnikom provodljivosti gasa Ar [18]. Njegova koncentracija je merena korišćenjem aparata za detektovanje propustljivosti (Argon Leak Detector Edwards LD 416, UK) [18]. Zubi su fiksirani u komorici pomoću držača radi stabilnosti, gde je Ar uveden specijalnom mikrokanilom plasiranom u krunični deo kanala zuba, posle čega je komora aparata vakuumirana. Vreme (sek.) koje je potrebno da gas prodre kroz apeks je mereno tajmer-detektorom (Argon LD 416, UK) [19]. Kvalitet hermetičnosti je izražen kao vreme potrebno da Ar prodre kroz sve slojeve kanalskog punjenja, pri čemu je duži interval vremena za pojavu gasa u apeksu označavao bolji kvalitet opturacije i obratno.

Statistička obrada je podrazumevala analizu varijanse ANOVA za procenu srednjih vrednosti među eksperimentalnim grupama sa nivoom poverenja $\mathrm{p}=0,01$. Test Neweman-Keuls je služio za poređenje razlika između grupa.

\section{REZULTATI}

Dobijeni rezultati su prikazani u Tabeli 1 i na Grafikonu 1. Najbolje rezultate pokazala je kombinacija apeksnog čepa i Gutta Flow silera sa prosečnom brzinom prodora gasa od 269,4 sek., potom paste AH Plus i MTA čepa (258,5 sek.), dok je najveća gasna propustljivost uočena primenom Acroseal silera i MTA (255,2 sek.). Ova razlika nije bila statistički značajna ( $\mathrm{p}>0.01)$.

U grupi u kojoj je opturacija urađena bez apeksnog čepa MTA cementom najmanja gasna propustljivost je zabeležena posle primene paste Gutta Flow (186,7sek.), potom kod paste AH Plus (179,9 sek.), a najveća propustljivost je uočena posle korišćenja paste Acroseal (178,5 sek.). Razlika takođe nije bila statistički značajna $(\mathrm{p}>0.01)$.
Uzorci sa MTA čepom pokazali su statistički znatno manju vrednost difuzije Ar u odnosu na grupe čiji su kanali napunjeni samo endodontskim silerom bez MTA čepa $(\mathrm{p}<0.01)$.

\section{DISKUSIJA}

Kako se kalcijum-silikatni MTA materijal smatra bioaktivnim materijalom, on je u ovom istraživanju izabran kao apeksni čep jer ispoljava dobre fizičko-hemijske osobine: zadovoljavajuća adherentnost za dentin, pritisna čvrstoća i povoljna sila smicanja $[4,7,8,20,21]$. Osim toga, potvrđena su njegova biološka svojstva: biostimulativnost, osteokonduktivnost i antimikrobnost kako na animalnom modelu tako i u kliničkim uslovima (prekrivanje pulpe, pulpotomija, perforacije korena zuba) [4, $6,7,8,19,20]$.

Među brojnim metodama za otkrivanje i procenu propustljivosti kanalskog ispuna (metod bakterijske propustliivosti [21], električne struje [22], difuzije boje [2] i radioaktivnih čestica [23]), gasna propustljivost se takođe pokazala kao veoma precizan postupak u proceni kvaliteta opturacije. U literaturi se mogu naći radovi sa primenom različitih gasova $\left(\mathrm{Ar}, \mathrm{O}_{2}, \mathrm{~N}_{2}, \mathrm{CO}_{2}\right.$, drugi plemeniti gasovi, organski gasovi) $[18,19]$, što ponekad može otežati poređenje dobijenih rezultata.

Argon kao plemeniti gas izabran je u ovoj studiji zbog svoje hemijske inertnosti prema ispitivanim materijalima za opturaciju $[18,19]$.

Nedostatak metode gasne propustljivosti je u tome što prikazuje samo integralnu sveukupnu propustljivost markirnog agensa (Ar), ali ne i puteve njegovog prolaska. Kombinacija ove metode sa optičkom analizom uz pomoć XRD i spektrofotometrije mogla bi lakše i preciznije objasniti fenomen curenja [18, 24].

MTA kao predstavnik KS cementa je izabran na osnovu činjenice da je favorizovan u mnogim radovima $[4-9,15,25$, 26], ali i zbog svoje biokompatibilnosti, visoke alkalnosti i slabe rastvorljivosti $[2,27]$. Dobri rezultati dobijeni primenom MTA kao apeksnog čepa u našoj studiji mogli bi se objasniti njegovom malom rastvorljivošću usled upijanja vode i neznatnom ekspanzijom, što potvrđuju i drugi radovi $[8,9,12,23,27,28]$.

Primena iRoot (iR) cementa za punjenje kanala (kao filer i siler), kao i za reparaciju perforacija korenskog zida, pokazala je zadovoljavajuće rezultate [27] jer on ne sadrži aluminijumske čestice a sličan je varijanti belog MTA. iRoot se smatra pogodnim za punjenje kanala korena zbog svoje viskoznosti [28] pa se može koristiti kao siler-filer sa gutaperka kočićem ili bez njega [29].

Prednost kvaliteta opturacije gde se koristi MTA kao apeksni čep mogla bi se objasniti njegovom ekspanzijom prvih nekoliko sati nakon mešanja jer tada MTA pokazuje porast težine za oko $12 \%$ nakon potapanja u vodu u toku jednog dana [30].

Niska rastvorljivost i dobra adhezija za kanalske zidove Gutta Flow silera i paste AH Plus su potvrđene u nekim ispitivanjima $[17,18,31,32]$. Slične rezultate sa nalazima ovog istraživanja potvrđuju i Bracket sa sar. [33], kao i Bouillaguet i sar. [34], ali tek posle 12 meseci. Bouillaguet i sar. [34] smatraju da je kod monokone tehnike opturacije zapremina silera mnogo veća od same mase gutaperke pa ovaj nepovoljan odnos utiče na stvaranje praznih prostora usled kontrakcije. Ovi autori smatraju da je za lošu adherenciju i veću propustljivost silera AH-Plus odgovorna neadekvatna veza između silera i gutaperka kočića, 
koja dozvoljava fluidnu filtraciju na njihovom međuspoju. Oni smatraju da pritisak postolja takođe doprinosi boljoj adherenciji Gutta Flow od paste AH plus pa time i manjoj apeksnoj mikropropustljivosti.

Martin RL [35] ispituje bakterijsku penetraciju u kanalima i nalazi bolje zaptivanje silera AH Plus nego kod uzoraka ispunjenih pastom Gutta Flow. On to objašnjava boljim adhezivnim osobinama paste AH Plus.

Acroseal $\mathrm{Ca}(\mathrm{OH})_{2}$ siler je pokazao u našem eksperimentu neadekvatno odnosno najslabije zaptivanje, što je u saglasnosti sa sličnim studijama $[34,36]$. Objašnjenje daju Mc Michen i sar. [37] u vezi sa stepenom rastvorljivosti koji pokazuje da AH Plus ima bolje osobine vezane za nerastvorljivosti od pasti na bazi $\mathrm{Ca}(\mathrm{OH})$, Slično tome, i u našem ispitivanju je Acroseal pokazao slabiju apeksnu hermetičnost u odnosu na AH Plus preparat. Objašnjenje za bolju apeksnu hermetičnost primećenu kod kanala ispunjenih MTA čepom u odnosu na one opturisane samo silerom i gutaperkom se može naći u studiji Guvena i sar. [38]. Oni smatraju da nanostrukture kod mineral-trioksidnog agregata dozvoljavaju da materijal penetrira u dentinske tubule i interreaguje sa vlagom unutar njih kako bi se ostvarilo završno očvršćavanje. Time se ostvaruje mehanička veza sa dentinom, a materijal poprima izvanrednu dimenzionu stabilnost. $U$ tom smislu fabrikovane su razne varijante MTA preparata, koje su se pripremale bilo sa vodom, bilo sa hidrosolubilnim gelom kako bi se poboljšala otpornost na ispiranje.

Danas usavršeni endodontski sileri na bazi MTA preskripcije (BioRoot $^{\mathrm{TM}}$ - RCS, MTA caps ${ }^{\mathrm{R}}, \mathrm{iR}^{\mathrm{R}}$, iR-BP Plus ${ }^{\mathrm{R}}$, MTA-Fillapex ${ }^{\mathrm{R}}$, Biodentine $^{\mathrm{TM}}$, Bioaggregate ${ }^{\mathrm{R}}$, ProRoot $\mathrm{MTA}^{\mathrm{R}}$ ) pokazuju veću otpornost na rastvaranje nego originalni MTA preparat, što pokazuju kako in vivo, tako i in vitro eksperimenti za retrogradno punjenje kanala korena zuba $[27,38,39]$. Za njihovu sigurniju primenu u praksi još uvek nedostaju opsežni klinički rezultati.

\section{ZAKLJUČAK}

Dobijeni rezultati su pokazali da je u svim uzorcima u kojima je MTA bio prethodno postavljen kao apeksni čep uočena značajno manja difuzija gasa u odnosu na uzorke opturisane standardnom tehnikom opturacije gutaperka kočićima bez apeksnog čepa. 